\title{
ОБОГАЩЕНИЕ ХЛЕБОБУЛОЧНЫХ ИЗДЕЛИЙ БЕЛКАМИ РАСТИТЕЛЬНОГО И ЖИВОТНОГО ПРОИСХОЖДЕНИЯ
}

\author{
А.С. Бушкарева (фото) \\ к.с.-Х.н., декан технологического факультета \\ Т.Г. Зубарева \\ старший преподаватель кафедры технологии производства \\ и переработки сельскохозяйственной продукции \\ ФГБОУ ВО Ярославская ГСХА, г. Ярославль
}

В современных условиях приоритетным направлением госу-

Хлеб, хлебобулочные

изделия, мука, белковые наполнители

растительного

происхождения,

белковые наполнители

животного

происхождения,

органолептическая оценка

Bread, bakery products, flour, vegetable protein fillers, animal protein fillers, organoleptic evaluation дарственной политики Российской Федерации является обеспечение системы здорового питания населения страны (распоряжение Правительства РФ от 25.10.2010 № 1873-р «Об основах государственной политики Российской Федерации в области здорового питания населения на период до 2020 года»).

Для решения названной проблемы предполагается ввести в рацион населения функциональные пищевые продукты, которые могли бы удовлетворить физиологические потребности организма человека в получении основных пищевых веществ.

Особенно важна, на наш взгляд, работа над повышением пищевой ценности хлеба и хлебобулочных изделий, так как именно они потребляются ежедневно, повсеместно и в больших количествах.

Качество хлеба и хлебобулочных изделий в значительной степени зависит от качества сырья, особенно муки. Хлебопекарные свойства муки зависят, прежде всего, от качества зерна, из которого она получена, а также от условий её производства и хранения [1].

K инновационным направлениям улучшения ассортимента хлебобулочных изделий в настоящее время относится выработка хлебобулочных изделий с увеличенной белковой ценностью. Цель обогащения хлебобулочных изделий - повышение обеспеченности организма человека витаминами и минеральными веществами, а также снижение существующего дефицита микронутриентов [2, 3].

Роль белка в жизни человека, его незаменимость как пищевого фактора и постоянно увеличивающийся дефицит его в питании привлекают внимание учёных и практиков к данной проблеме.

Во многих странах мира большое внимание уделяется растительному белку. Растительный белок используется в качестве добавок и как основной компонент комбинированных продуктов питания.

Для повышения пищевой ценности хлеба актуальным является также введение в рецептуру хлеба белковых обогатителей животно- 
го происхождения, содержащих большое количество незаменимых аминокислот [4].

\section{Методика}

Исследования проводились на базе кафедры технологии производства и переработки сельскохозяйственной продукции ФГБОУ ВО Ярославская ГСХА.

Цель исследований - оценка свойств хлебобулочных изделий, обогащённых белком растительного и животного происхождения.

Согласно поставленной цели были определены следующие задачи:

- изучить ассортимент пшеничного хлеба с белковыми наполнителями растительного и животного происхождения;

- выяснить, какое сырьё применяется для выработки пшеничного хлеба с белковыми наполнителями растительного и животного происхождения;

- провести выработку пшеничного хлеба с белковыми наполнителями растительного и животного происхождения в лабораторных условиях;

- оценить свойства выработанного хлеба с повышенной белковой ценностью.

Объекты исследований: образец 1 - пшеничный хлеб; образец 2 - пшенично-амарантовый хлеб; образец 3 - пшенично-соевый хлеб; образец 4 - пшенично-льняной хлеб; образец 5 - пшенично-овсяный хлеб; образец 6 - пшеничный хлеб, обогащённый альбумином.

Материалами для исследований послужили: мука льняная по ТУ 9146-004- 95947205-2011, мука соевая по ГОСТ 3898-56 «Мука соевая дезодорированная. Технические условия»; мука амарантовая по ТУ 9146-017-70834238-11; мука пшеничная по ГОСТ Р 52189-2003; мука овсяная по ТУ 10.61.22-695-37676459-2017; сухой молочный альбумин по требованиям ТУ 9229-062-046102092002 «Масса альбуминная из подсырной сыворотки»[5]; соль поваренная пищевая согласно ГОСТ Р 515774-2000 «Соль поваренная пищевая. Технические условия» [6]; дрожжи сухие согласно ТУ 9182-036-48975583-2010; вода питьевая согласно ГОСТ Р 51232-98 «Вода питьевая. Общие требования к организации и методам контроля качества» [7]. При оценке качества готовых хлебобулочных изделий учитывались органолептические и физико-химические показатели.

Для оценки физико-химических свойств хлебобулочных изделий были выбраны следующие показатели: пористость мякиша, кислотность мякиша, влажность и содержание белка. Определение пористости и кислотности мякиша, влажность и содержание белка в хлебобулочных изделиях проводились по следующим методикам:

- пористость - с помощью прибора Журавлева по ГОСТ 5669-96 [8];

- кислотность хлебобулочных изделий определялась по ГОСТ 5670-51 [9];

- влажность хлеба устанавливали по ГОСТ 21094-75 [10];

- содержание белка определяли по ГОСТ 13496.4-93 «Корма, комбикорма, комбикормовое сырье. Методы определения содержания азота и сырого протеина» [11].

При органолептической оценке образцов хлебобулочных изделий учитывали: форму, поверхность, состояние мякиша, пористость, аромат (запах), вкус.

Органолептическую оценку хлебобулочных изделий проводили в соответствии с балльной шкалой, представленной в таблице 1.

Работа проводилась согласно разработанной нами схеме исследований (рис. 1).

\section{Результаты исследований}

В ходе исследований было установлено оптимальное количество муки из культур с повышенной белковой ценностью для внесения в базовый рецепт.

Согласно рекомендациям Пучковой Л.И. и исследованиям, проводимым ранее на кафедре технологии производства и переработки сельскохозяйственной продукции, оптимальным считается внесение мук, обладающих специфическим вкусом, в пределах 5-6\%. Это количество позволяет сохранить органолептические свойства хлеба и в то же время обогатить его белком [13].

Нами была составлена технологическая схема выработки хлеба (рис. 2), обогащённого белком растительного и животного происхождения. Технологическая схема для выработки пшеничного хлеба, обогащённого белком в лабораторных условиях, включала в себя следующие операции: приёмка и подготовка сырья, замес теста, формование, расстойка теста, выпекание, охлаждение, хранение. Выработка хлебов проводилась в одинаковых условиях.

Согласно схеме, сначала провели замес теста, после чего все тестовые заготовки были направлены в расстоечный шкаф (ШРЛ-065 СПУ) для расстойки на 40 минут при температуре $24^{\circ} \mathrm{C}$. Далее осуществлялась выпечка хлеба в духовом шкафу в течение 30 минут при температуре $200^{\circ} \mathrm{C}$. После 
Таблица 1 - Шкала балльной оценки хлебобулочных изделий из смешанной муки [12]

\begin{tabular}{|c|c|c|}
\hline \multirow{2}{*}{$\begin{array}{l}\text { Показа- } \\
\text { тель }\end{array}$} & \multirow[b]{2}{*}{ Балл } & Хлеб формовой из смешанной муки \\
\hline & & $\begin{array}{l}\text { Соответствующие каждому баллу шкалы словесные характеристики отдельных показателей } \\
\text { качества изделий }\end{array}$ \\
\hline \multirow{5}{*}{ Форма } & 5 & Симметричная с заметно выпуклой верхней коркой \\
\hline & 4 & Достаточно симметричная относительно верхней корки \\
\hline & 3 & $\begin{array}{l}\text { Слишком округлая или недостаточно выраженная выпуклость верхней корки, немного } \\
\text { несимметричная относительно верхней корки }\end{array}$ \\
\hline & 2 & Плоская верхняя корка \\
\hline & 1 & Вогнутая верхняя корка \\
\hline \multirow{5}{*}{$\begin{array}{l}\text { Поверх- } \\
\text { ность }\end{array}$} & 5 & Гладкая (за исключением пшеничного обойного), без трещин и подрывов, глянцевая \\
\hline & 4 & Достаточно гладкая, едва заметные трещины и подрывы, глянцевая \\
\hline & 3 & $\begin{array}{l}\text { Слегка пузырчатая, шероховатая; заметные, но некрупные трещины } \\
\text { и подрывы, глянец слабый }\end{array}$ \\
\hline & 2 & Пузырчатая, бугристая, крупные трещины и подрывы, матовая поверхность \\
\hline & 1 & Разорванная корка, боковые притиски \\
\hline \multirow{5}{*}{$\begin{array}{l}\text { Состояние } \\
\text { мякиша }\end{array}$} & 5 & Очень мягкий, нежный, эластичный \\
\hline & 4 & Мягкий, эластичный \\
\hline & 3 & Удовлетворительно мягкий (немного уплотнённый), эластичный \\
\hline & 2 & Заметно уплотнённый, крошащийся, заметно заминающийся \\
\hline & 1 & Сильно заминающийся, влажный на ощупь, липкий \\
\hline \multirow{5}{*}{$\begin{array}{l}\text { Порис- } \\
\text { тость }\end{array}$} & 5 & Хорошо развитая и равномерная, поры мелкие и тонкостенные \\
\hline & 4 & Достаточно развитая и достаточно равномерная, поры мелкие и средние, тонкостенные \\
\hline & 3 & $\begin{array}{l}\text { Удовлетворительно развитая пористость, поры различной величины, средней } \\
\text { толщины, распределены неравномерно на срезе мякиша }\end{array}$ \\
\hline & 2 & $\begin{array}{l}\text { Поры мелкие, недоразвитые или крупные толстостенные, незначительное количество плот- } \\
\text { ных (беспористых) участков мякиша, разрыв мякиша, заметное отслоение мякиша от корки }\end{array}$ \\
\hline & 1 & $\begin{array}{l}\text { Оторванный от верхней корки и осевший мякиш, закал, плотный (неразрыхленный) мякиш, } \\
\text { следы непромеса }\end{array}$ \\
\hline \multirow{5}{*}{$\begin{array}{l}\text { Аромат } \\
(\text { запах })\end{array}$} & 5 & Интенсивно выраженный, характерный для данного вида изделий \\
\hline & 4 & Выраженный, характерный для данного вида изделий \\
\hline & 3 & Слабовыраженный, характерный для данного вида изделий \\
\hline & 2 & Невыраженный, слегка посторонний \\
\hline & 1 & Сильно кислый, посторонний, неприятный \\
\hline \multirow{5}{*}{ Вкус } & 5 & Интенсивно выраженный, характерный для данного вида изделий \\
\hline & 4 & Выраженный, характерный для данного вида изделий \\
\hline & 3 & Слабовыраженный, характерный для данного вида изделий \\
\hline & 2 & Пресноватый, слегка кислый, слегка тестовый \\
\hline & 1 & $\begin{array}{l}\text { Совершенно пресный, резко кислый, пересоленый, посторонний, неприятный, хруст на } \\
\text { зубах }\end{array}$ \\
\hline
\end{tabular}

выпечки и остывания хлебов, согласно методике исследований, была проведена оценка физикохимических показателей хлеба (пористость, \%; кислотность, град.; влажность, \%).

Физико-химические показатели исследуемых образцов хлеба представлены в таблице 2.
Согласно полученным результатам, у всех исследуемых образцов физико-химические показатели находились в пределах нормы.

Средняя пористость мякиша в выработанных образцах колебалась в пределах 56,70-74,5\%. У всех исследуемых хлебов с белковым наполни- 


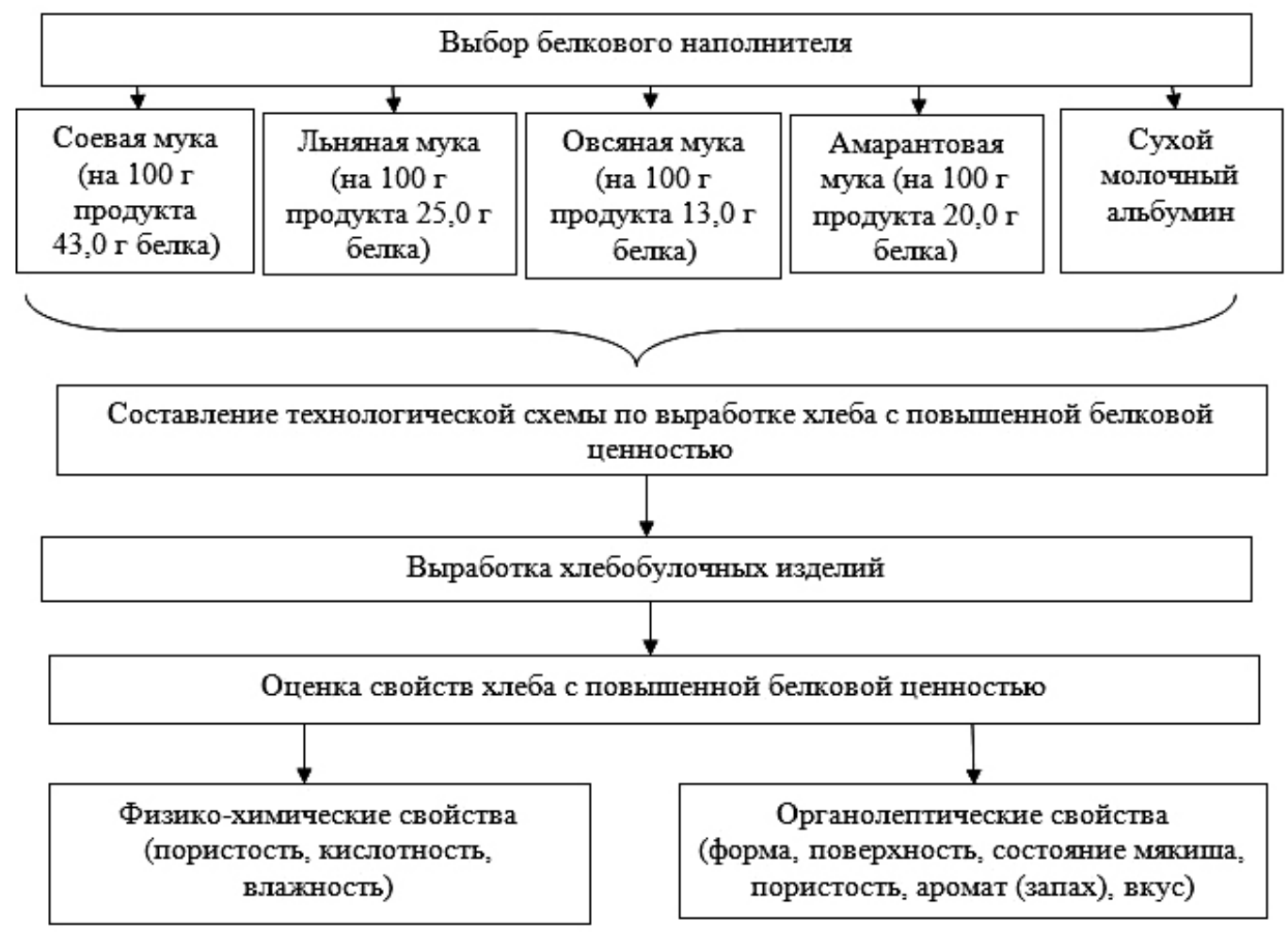

Рисунок 1 - Схема исследований

телем она была выше, чем у пшеничного хлеба без добавок, и изменялась от $62,2 \%$ у пшеничнольняного хлеба до 74,5\% у пшенично-альбуминового хлеба.

Кислотность у всех исследуемых образцов, кроме пшенично-амарантовогохлеба, былавыше, чем у пшеничного. Влажность выработанных хлебов была в пределах нормы. У пшенично-соевого и пшенично-овсяного образцов этот показатель был приближен к влажности пшеничного хлеба и составил 29,70 и $29,60 \%$ соответственно. Наиболее высокой влажностью отличались пшенич-

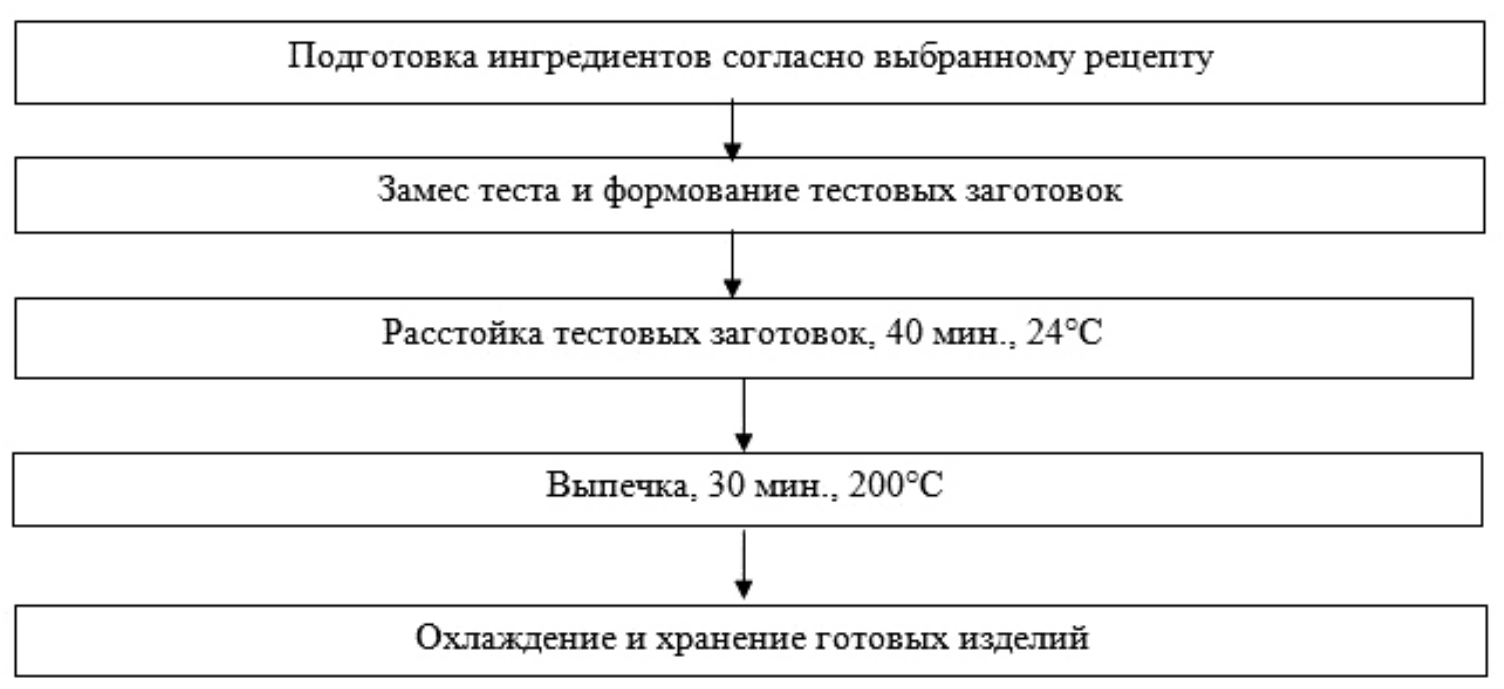

Рисунок 2 - Технологическая схема выработки хлеба, обогащённого белком растительного и животного происхождения 
Таблица 2 - Физико-химические показатели исследуемых образцов хлеба

\begin{tabular}{|c|c|c|c|c|c|c|}
\hline \multirow{2}{*}{$\begin{array}{c}\text { Наименование } \\
\text { продукта }\end{array}$} & \multicolumn{2}{|c|}{ Пористость хлеба, \% } & \multicolumn{2}{|c|}{ Кислотность хлеба, град. } & \multicolumn{2}{|c|}{ Влажность хлеба, \% } \\
\hline & по ГОСТ & опытная & по ГОСТ & опытная & по ГОСТ & опытная \\
\hline $\begin{array}{l}\text { Пшеничный хлеб } \\
\text { (контроль) }\end{array}$ & 50 и более & 56,70 & 3 и менее & 1,80 & 47 и менее & 29,20 \\
\hline $\begin{array}{l}\text { Пшенично-амарантовый } \\
\text { хлеб }\end{array}$ & \multirow{4}{*}{47 и более } & 69,60 & \multirow{4}{*}{ 9-11 и менее } & 1,80 & \multirow{4}{*}{50 и менее } & 32,80 \\
\hline Пшенично-соевый хлеб & & 65,40 & & 2,20 & & 29,70 \\
\hline Пшенично-льняной хлеб & & 62,20 & & 2,00 & & 31,20 \\
\hline Пшенично-овсяный хлеб & & 66,10 & & 2,20 & & 29,60 \\
\hline $\begin{array}{l}\text { Пшенично-альбуминовый } \\
\text { хлеб }\end{array}$ & 50 и более & 74,5 & 3 и менее & 2.9 & 47 и менее & 14,06 \\
\hline
\end{tabular}

но-амарантовый и пшенично-льняной хлеба. Содержание влаги в этих образцах составило 32,80 и $31,20 \%$ соответственно. Наименьшая влажность была у пшенично-альбуминового хлеба $14,06 \%$.

Основной задачей наших исследований было определение содержания белка в хлебах (табл. 3).
Как видно из данных таблицы 3, значения содержания белка в выработанных образцах хлеба колебались от 7,56 до $18,0 \%$. Наибольшее содержание белка (18,0\%) было в пшенично-соевом хлебе. Наименьший показатель наблюдался у пшеничного хлеба (контроль) - 7,56\%. Содержание белка в пшенично-льняном и пшенично-

Таблица 3 - Содержание белка в образцах хлеба, \%

\begin{tabular}{|l|c|}
\hline \multicolumn{1}{|c|}{ Наименование продукта } & Содержание белка, \% \\
\hline Пшеничный хлеб (контроль) & 7,56 \\
\hline Пшенично-амарантовый хлеб & 14,2 \\
\hline Пшенично-соевый хлеб & 18,0 \\
\hline Пшенично-льняной хлеб & 10,4 \\
\hline Пшенично-овсяный хлеб & 8,5 \\
\hline Пшенично-альбуминовый & 14,5 \\
\hline
\end{tabular}

овсяном хлебах составило 10,4 и $8,5 \%$ соответственно.

Так как хлеб является наиболее покупаемым продуктом, нас интересовали и его потребительские свойства. В связи с этим была проведена органолептическая оценка образцов хлеба (табл. 4), согласно в методике исследований, приведённой выше (табл. 1).

Органолептическую оценку проводили 6 экспертов. Результаты балльной оценки колебались незначительно, в пределах 26,8-24,6 баллов.

Согласно результатам таблицы 4, наибольшее количество баллов набрал пшенично-альбуминовый и пшенично-овсяный хлеб, их оценка составила 29,1 и 26,8 баллов соответственно.

Если рассматривать органолептическую оценку хлебов по отдельным показателям, то по внешнему виду было отдано предпочтение пше- нично-альбуминовому и пшенично-амарантовому хлебу. Оценочной комиссией также был отмечен пшенично-овсяный хлеб.

По вкусовым качествам наиболее высоко оценили пшеничный, пшенично-альбуминовый и пшенично-овсяный хлеба.

По состоянию мякиша и пористости наивысшую оценку получили пшенично-альбуминовый и пшенично-соевый хлеб.

\section{Bubod}

Таким образом, наши исследования показали целесообразность использования белковых обогатителей как растительного, так и животного происхождения при производстве хлеба. Введение в рецептуру хлеба муки повышенной белковой ценности или сухого молочного альбумина позволит не только повысить пищевую ценность 
Таблица 4 - Результаты органолептической оценки исследуемых образцов хлеба по 5-балльной шкале

\begin{tabular}{|c|c|c|c|c|c|c|c|}
\hline \multirow[b]{2}{*}{ Наименование продукта } & \multicolumn{7}{|c|}{ Свойства хлеба, балл } \\
\hline & Форма & Поверхность & $\begin{array}{c}\text { Состояние } \\
\text { мякиша }\end{array}$ & Пористость & $\begin{array}{c}\text { Аромат } \\
\text { (запах) }\end{array}$ & Вкус & $\begin{array}{l}\text { Общая } \\
\text { оценка }\end{array}$ \\
\hline Хлеб пшеничный (контроль) & 3,3 & 4,0 & 3,6 & 4,3 & 4,6 & 4,6 & 24,6 \\
\hline Хлеб пшенично-амарантовый & 4,8 & 4,6 & 4,3 & 4,0 & 4,1 & 3,5 & 25,4 \\
\hline Хлеб пшенично-соевый & 3,8 & 3,1 & 5,0 & 5,0 & 4,6 & 3,8 & 25,4 \\
\hline Хлеб пшенично-льняной & 4,8 & 4,1 & 4,8 & 4,1 & 4,1 & 4,3 & 26,4 \\
\hline Хлеб пшенично-овсяный & 4,0 & 4,8 & 4,1 & 5,0 & 4,0 & 4,8 & 26,8 \\
\hline Хлеб пшенично-альбуминовый & 5,0 & 4,7 & 5,0 & 5,0 & 4,6 & 4,8 & 29,1 \\
\hline
\end{tabular}

изделий, но и улучшить их потребительские свойства. По результатам комплексной оценки наилучшими физико-химическими и органолеп- тическими свойствами обладают пшенично-альбуминовый, пшенично-соевый и пшенично-овсяный хлеб.

\section{Лumepamypa}

1. Пашук, 3.Н. Технология производства хлебобулочных изделий [Текст]: справочник / 3.Н. Пашук, Т.К. Апет, И.И. Апет. - СПб.: ГИОРД, 2011. - 400 с.

2. Казарцева, А.Т. Овес - культура многофункционального использования [Текст] / А.Т. Казарцева, Н.В. Сокол // Труды Кубанского государственного аграрного университета. - 2014. - № 49. - С. 29-33.

3. Тарасова, В.В. Применение физиологически функциональных ингредиентов в производстве хлебобулочных изделий [Текст] / В.В. Тарасова // Пищевая промышленность. - 2014. - № 3. - С. 34 - 39

4. Манжесов, В.И. Основные итоги научной работы кафедры технологии переработки растениеводческой продукции Воронежского ГАУ / В.И. Манжесов, Т.Н. Тертычная, С.В. Калашникова, И.В. Максимов, С.Ю. Чурикова, М.В. Аносова // Известия вузов. Пищевая технология. - 2013. - № 2-3. - С. 11-15.

5. ТУ 9229-062-04610209-2002 «Масса альбуминная из подсырной сыворотки» [Текст]. - ИПК: ГНУ ВНИИМС, 2002. - 13 c.

6. ГОСТ Р 515774-2000 «Соль поваренная пищевая. Технические условия» [Текст]. - Стандартинформ, 2005. - 15 C.

7. ГОСТ Р 51232-98 «Вода питьевая. Общие требования к организации и методам контроля качества» [Текст]. - Стандартинформ, 2010. - 18 с.

8. ГОСТ 5669-96. «Хлебобулочные изделия. Метод определения пористости» [Текст]. - ИПК: Изд-во стандартов, 2001. - 5 с.

9. ГОСТ 5670-51. «Хлебобулочные изделия. Методы определения кислотности» [Текст]. - ИПК: Изд-во стандартов, 1997. - 8 с.

10. ГОСТ 21094-75. «Хлеб и хлебобулочные изделия. Метод определения влажности» [Текст]. - ИПК: Изд-во стандартов, 2002. - 3 с.

11. ГОСТ 13496.4-93 «Корма, комбикорма, комбикормовое сырье. Методы определения содержания азота и сырого протеина» [Текст]. - Стандартинформ, 2011. - 15 с.

12. Оценка качества продуктов питания. Оценка качества хлеба, основы анализа продуктов [Электронный ресурс]. - Режим доступа: http://www.matrixplus.ru/tooa20.htm).

13. Пучкова, Л.И Лабораторный практикум по технологии хлебопекарного производства [Текст] / Л.И. Пучкова. - 4-е изд., перераб. и доп. - СПб.: ГИОРД, 2004. - 264 с.: ил.

\section{References}

1. Pashuk, Z.N. Tehnologija proizvodstva hlebobulochnyh izdelij [Tekst]: spravochnik / Z.N. Pashuk, T.K. Apet, I.I. Apet. - SPb.: GIORD, 2011. -400 s.

2. Kazartseva, A.T. Oves - kul'tura mnogofunkcional'nogo ispol'zovanija [Tekst] / A.T. Kazartseva, N.V. Sokol // Trudy Kubanskogo gosudarstvennogo agrarnogo universiteta. - 2014. - № 49. - S. 29-33.

3. Tarasova, V.V. Primenenie fiziologicheski funkcional'nyh ingredientov $v$ proizvodstve hlebobulochnyh izdelij [Tekst] / V.V. Tarasova // Pishhevaja promyshlennost'. - 2014. - № 3. - S. 34 - 39 
4. Manzhesov, V.I. Osnovnye itogi nauchnoj raboty kafedry tehnologii pererabotki rastenievodcheskoj produkcii Voronezhskogo GAU /V.I. Manzhesov, T.N.Tertychnaya, S.V. Kalashnikova, I.V. Maksimov, S.Yu.Churikova, M.V. Anosova // Izvestija vuzov. Pishhevaja tehnologija. - 2013. - № 2-3. - S. 11-15.

5. TU 9229-062-04610209-2002 «Massa al'buminnaja iz podsyrnoj syvorotki» [Tekst]. - IPK: GNU VNIIMS, 2002. $-13 \mathrm{~s}$.

6. GOST R 515774-2000 «Sol' povarennaja pishhevaja. Tehnicheskie uslovija» [Tekst]. - Standartinform, 2005. $-15 \mathrm{~s}$.

7. GOST R 51232-98 «Voda pit'evaja. Obshhie trebovanija k organizacii i metodam kontrolja kachestva» [Tekst]. - Standartinform, 2010. - $18 \mathrm{~s}$.

8. GOST 5669-96. «Hlebobulochnye izdelija. Metod opredelenija poristosti» [Tekst]. - IPK: Izd-vo standartov, 2001. $-5 \mathrm{~s}$.

9. GOST 5670-51. «Hlebobulochnye izdelija. Metody opredelenija kislotnosti» [Tekst].- IPK: Izd-vo standartov, 1997. $-8 \mathrm{~s}$.

10. GOST 21094-75. «Hleb i hlebobulochnye izdelija. Metod opredelenija vlazhnosti» [Tekst]. - IPK: Izd-vo standartov, 2002. $-3 \mathrm{~s}$.

11. GOST 13496.4-93 «Korma, kombikorma, kombikormovoe syr'e. Metody opredelenija soderzhanija azota i syrogo proteina» [Tekst]. - Standartinform, 2011. - $15 \mathrm{~s}$.

12. Ocenka kachestva produktov pitanija. Ocenka kachestva hleba, osnovy analiza produktov [Jelektronnyj resurs]. - Rezhim dostupa: http://www.matrixplus.ru/tooa20.htm).

13. Puchkova, L.I Laboratornyj praktikum po tehnologii hlebopekarnogo proizvodstva [Tekst] / L.I. Puchkova. - 4-e izd., pererab. i dop. - SPb.: GIORD, 2004. - 264 s.: il.

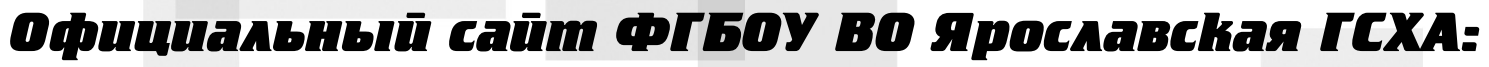 www.yaragrovuz.ru

\author{
РУБРИКИ САЙТА:
}

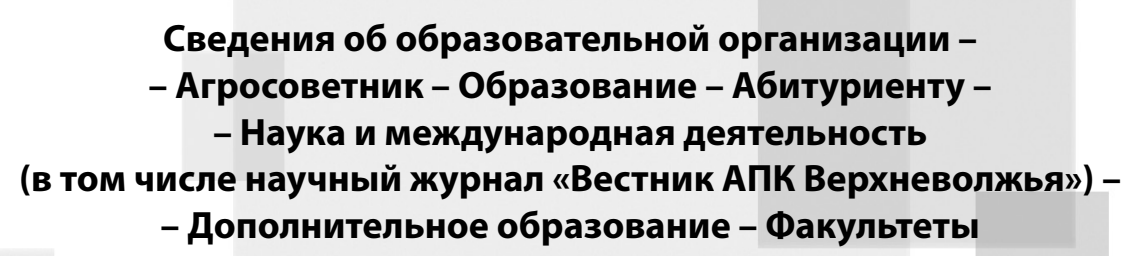

Все выпуски журнала «Вестник АПК Верхневолжья» в полнотекстовом формате, требования к оформлению рукописей, контакты на страничке:

http://yaragrovuz.ru/index.php/nauka-i-mezhdunarodnaya-deyatelnost/zhurnal-vestnik-apk-vekhnevolzhya 